\title{
Genetic Variants and Allele Frequencies of Kappa Casein in Egyptian Cattle and Buffalo Using PCR-RFLP
}

\author{
Eman M. Gouda ${ }^{1}$, Mona Kh. Galal ${ }^{1} \&$ Samy A. Abdelaziz ${ }^{1}$ \\ ${ }^{1}$ Biochemistry Department, Faculty of Veterinary Medicine, Cairo University, Giza, Egypt \\ Correspondence: Eman M. Gouda, Biochemistry Department, Faculty of Veterinary Medicine, Cairo University, \\ Giza, Egypt. E-mail: emanmgouda@hotmail.com
}

Received: October 9, 2012

Accepted: October 24, 2012 Online Published: January 15, 2013

doi:10.5539/jas.v5n2p197

URL: http://dx.doi.org/10.5539/jas.v5n2p197

\begin{abstract}
Kappa casein (K-Ca) genetic variations affected quality and composition of the milk. Several variants of Kappa casein (K-Ca) gene locus IV have been reported with special interest for the 'B' allele for its relation to the milk protein and fat yields. Genotyping and allelic frequencies of K-Ca among Native Egyptian breeds of cattle and buffalo were the aim of the present study. PCR amplification of DNA isolated from 300 blood samples collected from Holstein and Baladi cattle and buffalo were performed followed by restriction fragment length polymorphism using Hind-III restriction endonuclease (PCR-RFLP). Detection of 'AA' and 'AB' genotypes in cattle breeds, 'BB' and ' $\mathrm{AB}$ ' in buffalo and two alleles ' $\mathrm{A}$ ' and ' $\mathrm{B}$ ' in the studied breeds. Molecular selection for animals carrying the ' $\mathrm{B}$ ' allele could impact breeding programs for dairy production in native cattle and buffalo breeds in Egypt.
\end{abstract}

Keywords: Kappa casein, polymorphism, cattle, buffalo PCR-RFLP

\section{Introduction}

Improvement of milk yield and its composition is the primary goal for animal selection in dairy industry. Animal selection on the basis of molecular markers considered to be more reliable than any other criterion (Riaz et al., 2008), as the using of DNA polymorphic markers allows the determination of individual genotypes at many loci and provides information on population parameters like allelic and genotypic frequencies which can be used as a tool for improving the animal selection through marker assisted selection (Kumar et al., 2006). Milk proteins polymorphism has attracted intensive research interest because its potential use as an aid to genetic selection of bovine breeds (Kemenes et al., 1999). Several studies have been reported that, milk protein variants, particularly caseins are associated with lactation performance and have major influence on milk composition and its processing properties (Kastonina et al., 2004; Denisenko \& Kalashnikova, 2004; Konovalova et al., 2004). Polymorphism of casein gene has been intensely studied in different cattle breeds (Ceriotti et al., 2004; Wedholm et al., 2006). The association between K-Ca alleles and the total protein content, fat percentage and milk production was observed in several studies (Tsiaras et al., 2005, Verdier- Metz et al., 2001; Boettcher et al., 2004; Kubarsepp et al., 2005). The total size of k-Ca gene was about 13 KD (Alipanah et al., 2007) divided into 5 exons, with several genetic variants in different species. 'A' and ' $\mathrm{B}$ ' alleles were the most common variants among it. K-Ca 'B' allele was reported to have a favorable and significant effect on both milk yield and milk protein content in Reggiana dairy local cattle (Caroli et al., 2004), different Indian buffaloes breeds (Raj et al., 2008), nili-ravi buffalo (Riaz et al., 2008). Also, its favorable effect on milk technological properties and cheese yield in taurine and zebu cattle breeds (Ceriotti et al., 2004) and Brazilian cattle (Azevedo et al., 2008), desirable coagulation properties reported in Finnish Ayrshire cows (Ikonen et al., 1997).

Medrano and Aguilar-Cordova (1990) identified a restriction fragment length polymorphism (RFLP) at the K-Ca bovine locus and detected two alleles ' $\mathrm{A}$ ' and 'B' that were differed by two amino acid substitutions (Lin et al., 1992). Those K-Ca genotypes had highly significant effect on protein content such that 'BB' genotype was associated with high protein content than 'AA' genotype, also the cheese yield from cow with K-Ca 'BB' genotype was $10 \%$ higher than that of genotype 'AA' (Azevedo et al., 2008).

Using molecular markers allow direct genotyping for K-Ca; whose polymorphism has direct and potent effect on milk production, with accuracy to be used in dairy cattle improvement program. 
The objective of the current work was to identify the genotypes and allelic frequencies of K-Ca locus in Egyptian cattle and buffalo breeds aiming to improve the milk yield and composition through genetic selection in Egypt and to highlight its importance to be adopted elsewhere in the world dairy program.

\section{Material and Methods}

\subsection{Genomic DNA Isolation}

A total of 300 blood samples were collected from local Baladi breed of dairy cows, Holstein cattle and buffalo from different farms in Egypt, unrelated individuals following the recommendations suggested by ISAG/FAO advisory group on animal genetic diversity $(\mathrm{FAO}, 1998)$. Blood samples were collected in $\mathrm{K}_{3}$-EDTA coated sterile vacationers and stored at $-20^{\circ} \mathrm{C}$ until used for genomic DNA extraction.

Genomic DNA was extracted from each blood sample according to Sambrook et al. (1989). The quality of the DNA was checked on $1 \%$ agarose gel.

\subsection{PCR Amplification}

A 379 bp fragment containing exonIV of K-Ca gene was amplified through PCR using forward K-F: 5'-CACGTCACCCACACCCACATTTATC-3' and reverse K-R: 5' -TAATTAGCCCATTTCGCCTTCTCTGT-3' primers (Mitra et al., 1998). The PCR mixture composed of $5_{\mathrm{x}}$ PCR master mix (Jena BioScience ${ }^{\mathrm{TM}}$ ), 25 pmol from each primer, $1 \mu \mathrm{l}$ from BSA, $50 \mathrm{ng}$ of genomic DNA and sterilized distilled water to make a final volume of $25 \mu \mathrm{l}$. The PCR reaction included pre-denaturation for $5 \mathrm{~min}$ at $95^{\circ} \mathrm{C}$ followed by 35 cycles at $95^{\circ} \mathrm{C}$ for $1 \mathrm{~min}, 64^{\circ} \mathrm{C}$ for $90 \mathrm{sec}, 72^{\circ} \mathrm{C}$ for $1 \mathrm{~min}$ and a final extension of $10 \mathrm{~min}$ at $72^{\circ} \mathrm{C}$.

\section{$2.3 \mathrm{~K}$-Ca Genotyping Using RFLP}

The PCR products were digested with Hind-III restriction enzyme to discriminate the different allelic variant for K-Ca (Rottmann \& Schlee, 1992). The restriction digestion was performed in a total volume of $25 \mu \mathrm{l}(15 \mu \mathrm{l}$ of PCR product, $2.5 \mu \mathrm{l}$ enzyme buffers, $0.5 \mu \mathrm{l}$ enzymes and $7 \mu \mathrm{l}$ distilled water) and placed in the incubator at $37^{\circ} \mathrm{C}$ for $3 \mathrm{~h}$. The restriction products were electrophoresed on $10 \%$ non-denaturing polyacrylamide gel and electrophoresed in 1 x TBE buffer ( $89 \mathrm{mM}$ Tris (hydroxymethyl) aminomethane-boric acid and $2 \mathrm{mM}$ EDTA) on a minislab gel at room temperature at $150 \mathrm{~V}$ for $5 \mathrm{~min}$, then at $80 \mathrm{~V}$ until the DNA bands migrated about $2 / 3$ of the gel (Rachagani et al., 2006). The gels were stained by Etheduim bromide $(1 \mathrm{mg} / \mathrm{ml})$ for $2 \mathrm{~min}$ and then destained in water for $15 \mathrm{~min}$.

\subsection{Statistical Analysis}

Direct counting was used to estimate genotyping and allele frequencies of K-Ca genetic variants. The chi-square test $\left(\chi^{2}\right)$ was used to check whether the populations were in Hardy-Weinberg equilibrium. Allele frequencies and mean expected heterozygosities per locus and population were calculated using Arlequin ver. 3.11 package programs (Excoffier \& Heckel, 2006).

\section{Results and Discussion}

Early and precise identification of milk protein polymorphism have great impact on dairy cattle breeding strategies (Scheepers et al., 2010). Using the PCR-RFLP technique for identification the genetic polymorphism in K-Ca allowed both rapid and efficient determination of the genetic variation in this gene regardless the age and sex of animals, leading to establishment and increasing the frequency of desired alleles among our Egyptian animals. Genotypes and allelic frequencies distribution for K-Ca gene in Egyptian Holstein, Baladi cattle and buffalos breeds were detected. In both cattle breeds the 'AA' \& 'AB' were detected with similar genetic frequencies and absence of 'BB' genotype with higher frequency of 'A' allele (0.63) in both breeds (Table 1). This is the first reported research on genotype and allele frequencies for K-Ca gene in native Egyptian Baladi cattle breed however, such reports are available for many other breeds like Anatolian Black and East Anatolian Red breeds of cattle (Gurses \& Yuce, 2012).

Hardy-Weinberg proportions tests are frequently used to check on random mating in populations and the deviations from expectation are used to estimate inbreed-ing coefficients. Some events, such as an accumulation of some genotypes, subdivision of the population, mutation, selection, migration, or endogamy can result in a state of disequilibrium within the population (Tambasco et al., 2000; Vasconcellos et al., 2003). Both cattle breeds were deviated from equilibrium which may be due to migration or subdivision.

The same results were detected in Anatolian black and East Anatolian red native cattle breeds of Turkey (Gurses \& Yuce, 2012). Red Pied (Alipanah et al., 2005), Black Pied cows (Doosti et al., 2011) and Romanian spotted cattle (Daniela et al., 2007). However, the 'A' allele frequency of the K-Ca gene of cattle identified in this study was still 
lower compared to the reported figures of some other countries such as USA, Europe, Brazil and Japan which having a higher ' $A$ ' allele frequency at a range of 0.8-0.9 (Swaisgood, 1992; Rachagani \& Gupta, 2008).

Table 1. The distribution of Kappa casein genotypes and allele frequencies in Holstein cattle, Baladi cattle and Buffalo in Egypt and Hardy-Weinberg equilibrium

\begin{tabular}{|c|c|c|c|c|c|c|}
\hline \multirow{2}{*}{\multicolumn{2}{|c|}{ Animal breed }} & \multicolumn{3}{|c|}{ Genotype } & \multicolumn{2}{|c|}{ Allelic frequency } \\
\hline & & AA & BB & $\mathrm{AB}$ & $\mathrm{A}$ & B \\
\hline \multirow{4}{*}{ Baladi cattle } & Obs & 26 & Zero & 74 & \multirow{4}{*}{0.63} & \multirow{4}{*}{0.37} \\
\hline & Exp & 39.69 & 13.69 & 46.62 & & \\
\hline & Genotype frequency & 0.26 & Zero & 0.74 & & \\
\hline & $x^{2}$ & 34.47 & & $0.0001^{\cdots n \mathrm{~s}}$ & & \\
\hline \multirow{4}{*}{ Holstein cattle } & Obs & 24 & Zero & 76 & \multirow{4}{*}{0.62} & \multirow{4}{*}{0.38} \\
\hline & Exp & 38.44 & 14.44 & 47.12 & & \\
\hline & Genotype frequency & 0.24 & Zero & 0.76 & & \\
\hline & $x^{2}$ & 37.54 & & $0.0001^{\cdots \cdots n}$ & & \\
\hline \multirow{4}{*}{ Buffalo } & Obs & Zero & 75 & 25 & \multirow{4}{*}{0.125} & \multirow{4}{*}{0.875} \\
\hline & Exp & 1.63 & 76.5 & 21.87 & & \\
\hline & Genotype frequency & Zero & 0.75 & 0.25 & & \\
\hline & $x^{2}$ & 2.099 & \multicolumn{2}{|c|}{ propapablity $0.1473^{\mathrm{NS}}$} & & \\
\hline \multirow{2}{*}{\multicolumn{2}{|c|}{ Animal breed }} & \multicolumn{3}{|c|}{ Genotype } & \multicolumn{2}{|c|}{ Allelic frequency } \\
\hline & & AA & $\mathrm{BB}$ & $\mathrm{AB}$ & $\mathrm{A}$ & $\mathrm{B}$ \\
\hline \multirow{4}{*}{ Baladi cattle } & Obs & 26 & Zero & 74 & \multirow{4}{*}{0.63} & \multirow{4}{*}{0.37} \\
\hline & Exp & 39.69 & 13.69 & 46.62 & & \\
\hline & Genotype frequency & 0.26 & Zero & 0.74 & & \\
\hline & $x^{2}$ & 34.47 & & $0.0001^{m n \pi s}$ & & \\
\hline \multirow{4}{*}{ Holstein cattle } & Obs & 24 & Zero & 76 & \multirow{4}{*}{0.62} & \multirow{4}{*}{0.38} \\
\hline & Exp & 38.44 & 14.44 & 47.12 & & \\
\hline & Genotype frequency & 0.24 & Zero & 0.76 & & \\
\hline & $\chi^{2}$ & 37.54 & & $0.0001^{\cdots n \pi s}$ & & \\
\hline \multirow{4}{*}{ Buffalo } & Obs & Zero & 75 & 25 & \multirow{4}{*}{0.125} & \multirow{4}{*}{0.875} \\
\hline & Exp & 1.63 & 76.5 & 21.87 & & \\
\hline & Genotype frequency & Zero & 0.75 & 0.25 & & \\
\hline & $\chi^{2}$ & 2.099 & \multicolumn{2}{|c|}{ propapablity $0.1473^{\mathrm{NS}}$} & & \\
\hline
\end{tabular}

$\chi^{2}=$ chi-square value; Obs.: observed frequencies; Exp.: expected frequencies on the basis of Hardy-Weinberg law. *** Statistically significant, the population is in Hardy-Weinberg frequencies (is not rejected).

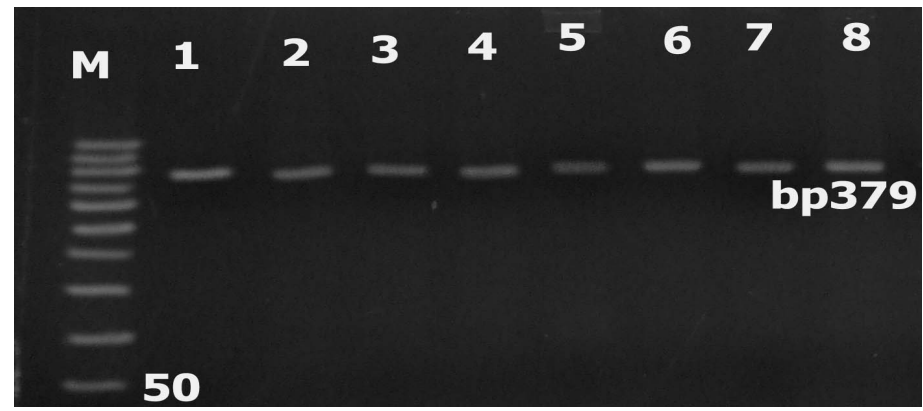

Figure 1. Electrophoresis of Kappa casein gene PCR products on $2 \%$ agarose gel

Agarose gel (2\%) showing PCR products of Kappa casein of Baladi cattle (lanes 1-3), Holstien cattle (lanes 4\&5), and buffalo (lanes 6-9). All lanes showing a single specific band with 379 bp expected size. Lane M represents the 50 bp DNA molecular weight marker (Jena BioScience ${ }^{\mathrm{TM}}$ ). 


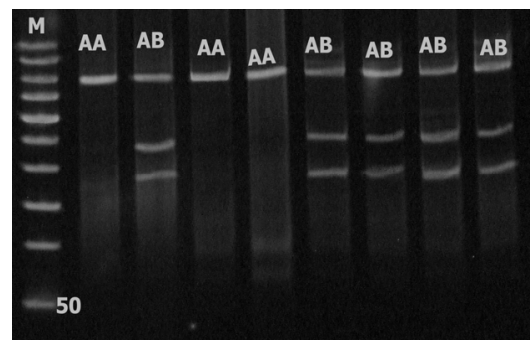

A. The RFLP patterns of the k-casein gene after digestion with hindIII on $10 \%$ polyacrylamide gel with $50 \mathrm{pb}$ ladder as Molecular Marker in Holstein cattle.

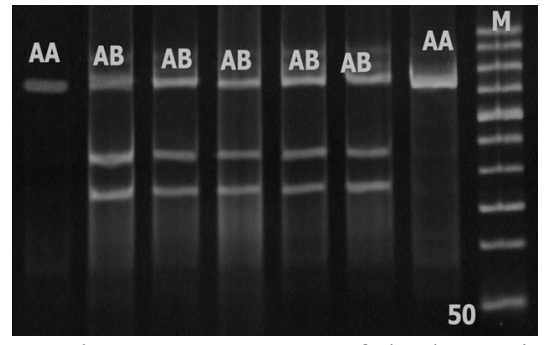

B. The RFLP patterns of the k-casein gene after digestion with hindIII on $10 \%$ polyacrylamide gel with $50 \mathrm{pb}$ ladder as Molecular Marker in Holestein cattle.

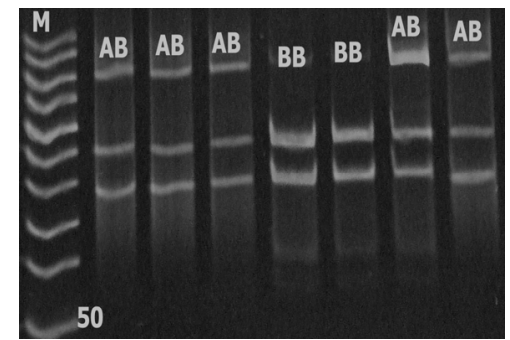

C. The RFLP patterns of the $\mathrm{k}$-casein gene after digestion with hindIII on $10 \%$ polyacrylamide gel with $50 \mathrm{pb}$ ladder as Molecular Marker in buffaloes .

Figure 2. Electrophoretic patterns of 379 bp PCR products of Kappa casein gene digested with Hind III endonuclease on $10 \%$ PAGE

On the other hand, Allmere et al. (1998) and Oner and Elmaci (2006) reported the presence of 'A' and 'B' alleles for K-Ca, with highest frequency ' $\mathrm{B}$ ' allele in Holstein breed. Cows with 'AB' and 'BB' genotypes showed significant higher milk proteins and fat content when compared with that of 'AA' genotype (Botaro et al., 2009) suggested that selection of cows with 'AA' genotype for meat production is preferred.

Regarding Egyptian buffaloes, absence of 'AA' genotype of K-Ca genotype, detection of 'BB' and 'AB' genotypes with extremely higher frequency of 'B' allele (0.875) were observed (Table 1). These results are in agreement with Singh et al. (2005), Patel et al. (2007). However, Pipalia et al. (2001), Ontaviano et al. (2005) Riaz et al. (2008) and Ren et al. (2011) reported that the K-Ca in buffalo is monomophic with only one allele ' $\mathrm{B}$ '.

Buffalo were found to be in Hardy-Weinberg equilibrium (Table 1), suggested that the Kappa casein gene was not influenced by selection.

Many researchers reported that K-Ca genotypes especially 'BB' one was related to the quality of milk and cheese making (Ikonen et al., 1999; Patil et al., 2003). Therefore, the 'BB' genotype in Holstein cattle seems better suited for improvement of the quality of milk and cheese making in Egypt. This genotype was absent in our cattle breed so we have recommended here direction to increases frequency of 'BB' genotype through genetic selection of breeding bulls carring 'BB' genotype through artificial insemination or direction of cattle breeds to meat production rather than milk production.

In conclusion K-Ca genetic polymorphism could be used as useful marker for genetic selection. Also our study can help in maintaining a high frequency of ' $\mathrm{B}$ ' allele as the favorable one for increasing milk quality and quantity in our commercial cattle breeds.

\section{References}

Alipanah, M., Kalashnikova, L., \& Rodionov, G. (2005). Kappa-casein genotypic frequencies in Russian breeds Black and Red Pied cattle. Iranian journal of biotechnology, 3(3), 2005.

Alipanah, M., Klashnikova, L., \& Rodionov, G. (2007). K caseingenotypic frequencies in Russian breed Black and Red Pied cattle. Iran J. Biotechnol, 3, 191-194.

Allmere, T., Andren, A., Lindersson, M., \& Jorck, L. (1998). Studies on rheological properties of stirred milk gels made from milk with defined genetic variants of kappa-casein and betalactoglobulin. Int. Dairy J., 8, 899-905. http://dx.doi.org/10.1016/S0958-6946(99)00012-6

Azevedo, L. S., Nascimento, C. S., Steinberg, R. S., Carvalho, R. S, Peixoto, C. D., Teodoro, R. L., ... Machado, M. A. (2008). Genetic polymorphism of the kappa-casein gene in Brazilian cattle. Genetics Molecular Research, 7, 623-630. http://dx.doi.org/10.4238/vol7-3gmr428

Boettcher, P. J., Caroli, A., Stella, A., Chessa, S., Budelli, E., Canavesi, F., ..Pagnacco, G. (2004). Effects of casein haplotypes on milk production traits in Italian Holstein and Brown Swiss cattle. J. Dairy Sci., 87, 4311-4317. http://dx.doi.org/10.3168/jds.S0022-0302(04)73576-6 
Botaro, B. G, Real de Lima, Y. V., Cortinhas, C. S, Prada e Silva, L. F., Renno, F. P., \& Veiga dos Santos, M. (2009). Effect of the kappa-casein gene polymorphism, breed and seasonality on physicochemical characteristics, composition and stability of bovine milk. R. Bras. Zootec. 38(12), 2447-2454. http://dx.doi.org/10.1590/S1516-35982009001200022

Caroli, A., Chessa, S., Bolla, P., Budelli, E., \& Gandini, G. C. (2004). Genetic structure of milk protein polymorphism and effects on milk production traits in local dairy cattle. J. Anim. Breed. Genet., 121, 119-127. http://dx.doi.org/10.1111/j.1439-0388.2003.00443.x

Ceriotti, G., Marletta, D., Caroli, A., \& Erhardt, G. (2004). Milk protein loci polymorphism in taurine (Bos taurus) and zebu (Bos indicus) populations bred in hot climate. Journal of Animal Breeding and Genetics, 121, 404-415. http://dx.doi.org/10.1111/j.1439-0388.2004.00471.x

Daniela, I., Salajeanu, A., Magdin, A., Stanca, C., Vintila, C., Vintila, I., ... Gocza, E. (2007). Genetic polymorphism at the k-casein locus in a dairy herd of Romanian Spotted and Brown of Maramures breeds, Lucrari ştiințifice Zootehnie si Biotehnologii. Timişoara, 40(1), 101-105.

Denisenko, E. A., \& Kalashnikova, L. A. (2004). Milk production of Black Pied breeds with difference genotypes of kappa casein. 4th conference problems biotechnology in farm animal. VIJ. Dobrovitsy (pp. 47-48). Russia. 24-25 November.

Doosti, A., Arshi, A., Vatankhah, M., \& Amjadi, P. (2011). Kappa-casein gene polymorphism in Holstein and Iranian native cattle by polymerase chain reaction restriction fragment length polymorphism (PCR-RFLP) African Journal of Biotechnology, 10(25), 4957-4960.

Excoffier, L., \& Heckel, G. (2006). Computer programs for population genetics data analysis: a survival guide. Nature Reviews Genetics, 7(10), 745-758. http://dx.doi.org/10.1038/nrg1904

FAO. (1998). Secondary Guidelines for Development of National Farm Animal Genetic Resources Management Plans. Measurement of Domestic Animal Diversity (MoDAD): Original Working Group Report (p. 55). Rome. Retrieved from http://www.fao.org/ag/againfo/resources/en/pubsgen.html

Gurses, M., \& Yuce, H. (2012). Determination of kappa casein gene polymorphism and their effects on milk composition in some native cattle breeds of Turkey. J. of animal and vet adev., 11(7), 1023-1027.

Gurses, M., \& Yuce, H. (2012). Determination of Kappa Casein Gene Polymorphisms and Their Effects on Milk Composition in Some Native Cattle Breeds of Turkey. J. of animal and veterinary Advances, 11(7), 1023-1027.

Ikonen, T., Ahlfors, K., Kempe, R., Ojala, M., \& Ruottinen, O. (1999). Genetic parameters for the milk coagulation properties and prevalence of noncoagulating milk in Finnish dairy cows. J. Dairy Sci., 82, 205-214. http://dx.doi.org/10.3168/jds.S0022-0302(99)75225-2

Ikonen, T., Ojala, M., \& Ruottinen, O. (1997). Association between milk protein polymorphism and first lactation milk production traits in Finnish Ayrshire cows. J. Dairy Sci., 82, 205-214. http://dx.doi.org/10.3168/jds.S0022-0302(99)75225-2

Kastonina, O. V, Khripiakov, E. N., Strikozov, N. I., \& Zinoveva, N. A. (2004). Effects differences genotype kappa-casein, Beta-lactogolubin and alpha-lactoalbumin on technological effects of milk. $4^{\text {th }}$ conference problems biotechnology in farm animal (pp. 54-60). VIJ Dobrovitsy. Russia. 24-25 November.

Kemenes, P. A., Reginato, L. C. A., Rosa, A. J. M., Parker, I. U., Razook, G. A., Figueiredo, L. A., ... Coutinh, L. L. (1999). k-casein, b-lactoglobulin and growth hormone allele frequencies and genetic distances in Nelore, Gyr, guzera, Caracu, Charolais, Canchin and Santa Gertrudis cattle. Genet. Mol. Biol., 22, 539-541. http://dx.doi.org/10.1590/S1415-47571999000400012

Konovalova, E. N., Seltcov, V. I., \& Zinoveva, N. A. (2004). Polymorphism gene kappa casein and its effects on production traits cows Simmental breeds. 4th conference problems biotechnology in farm animal (pp. 49-54). Dobrovitsy Russia. 24-25. November.

Kubarsepp, I. M., Henno, M., Viinalass, H., \& Sabre, D. (2005). Effect of $\kappa$-casein and $\beta$-lactoglobulin genotypes on the milk rennet coagulation properties. Agr. Res., 1, 55-64.

Kumar, D., Gupta, N., Ahlawat, S., Satyanarayana, R., Sunder, S., \& Gupta, S. (2006). Single strand confirmation polymorphism (SSCP) detection in exon I of the lactalbumin gene of Indian Jamunapri milk goats (Capra hircus). Genetic Mol Biol, 29, 271-274. http://dx.doi.org/10.1590/S1415-47572006000200016 
Lin, C. Y., Sabour, M. P., \& Lee, A. J. (1992). Direct typing to milk proteins as an aid for genetic improvement of dairy bulls and cows: A review. Animal Breeding Abstracts, 60, 1-10.

Medrano, J., \& Aguilar-Cordova, E. (1990). Polymerase chain reaction amplification of bovine $\beta$-lactoglobulin genomic sequences and identification of genetic variants by RFLP analysis. Anim. Biotechnol., 1, 73-77. http://dx.doi.org/10.1080/10495399009525730

Mitra, A., P., Schlee, I., Krause, J., Blusch, T., Werner, C. R., Bala, K., \& Pirchner, F. (1998). Kappa casein polymorphism in the Indian dairy cattle and buffalo: A new genetic variant in buffalo. Anim Biotechnol 9 , 81-87. http://dx.doi.org/10.1080/10495399809525896

Oner, Y., \& Elmaci, C. (2006). Milk protein polymorphisms in Holstein cattle. Int. J. Dairy Technol., 59, 180-182. http://dx.doi.org/10.1111/j.1471-0307.2006.00259.x

Ontaviano, R., Tonhati, H., Desiderio J. A., \& Munoz, F. C (2005): Kappa-casein gene study with molecular marker in female buffalos. Gene and Mol. Biol., 28(2), 237-241. http://dx.doi.org/10.1590/S1415-47572005000200010

Patel, J. B., Chauhan, K. M. S., \& Soni, K. J. (2007). Genotyping and alleleic frequencies of $\kappa-\mathrm{CN}$ and $\beta$-LG in Indian river buffalo bulls. Buffalo Bull., 26(3), 63-66.

Patil, M. R., Borkhatriya, V. N., Boghra, V. R., \& Sharma, R. S. (2003). Effect of bovine milk kappa-casein genetic polymorphs on curd characteristics during cheddar cheese manufacture. J. Food Sci. Tech., 40, 582-586.

Pipalia, D., Ladani, D., Brahmkshtri, B., Rank, D., Joshi, C., Vataliya, P., ... Solanki, J. (2001). Kappa-casein genotyping of Indian Buffalo breeds using PCR-RFLP. Buffalo J., 17, 195-202.

Rachagani, S., \& Gupta, I. D. (2008). Bovine kappa-casein gene polymorphism and its association with milk production traits. Genetics and Molecular Biology, 31(4), 893-897. http://dx.doi.org/10.1590/S1415-47572008005000001

Rachagani, S., Gupta, I. D., Gupta, N., \& Gupta, S. C. (2006). Genotyping of beta lactoglobulin gene by PCR-RFLP in Sahiwal and Tharparkar cattle breeds. BMC Genetics, 7, 31-34. httpo://dx.doi.org/10.1186/1471-2156-7-31

Raj, G. D., Shetty, S., Govindaiah, M. G., Nagaraja, C. S., Byregowda, S. M., \& Jayashankar, M. R. (2008) Molecular characterization of Kappa-casein in buffaloes. Science Asia, 34, 435-549. http://dx.doi.org/10.2306/scienceasia1513-1874.2008.34.435

Ren, D. X., Miao, S. Y., Chen, Y. L., Zou, C. X., Liang, X. W., \& Liu, J. X. (2011). Genotyping of the k-casein and B-lactoglobulin genes in Chinese Holstein, Jersey and water buffalo by PCR-RFLP. Journal of Genetics, 90(1).

Riaz, M. N., Malik, N. A., Nasreen, F., \& Qureshi, J. A. (2008). Molecular marker assisted study of kappa-casein gene in nili-ravi (buffalo) breed of Pakistan. Pakistan vet. J., 28(3), 103-106.

Sambrook, J., Fritch, E. F., \& Maniatis, T. (1989). Molecular Cloning: A Laboratory Manual (2 edn.).New York: Cold Spring Harbor Laboratory Press.

Scheepers, R. C, Marle-Köster, E., \& Visser, C. (2010). Genetic variation in the kappa-casein gene of South African goats. Small Rumin. Res., 93, 53-56. http://dx.doi.org/10.1016/j.smallrumres.2010.03.007

Singh, S., Pushpendra, K., \& Bhattacharya, T. K. (2005). DNA polymorphism of $\kappa-\mathrm{CN}$ and $\beta$-CN genes and its association with milk production and quality traits in buffalo (B. bubalis). Proceeding of National Symposium on Domestic Animals Diversity: Status, Opportunities and Challenges, Karnal, India.

Swaisgood, H. E. (1992). Chemistry of Caseins. In P. F. Fox (Ed.), Advanced Dairy Chemistry-1 Proteins (pp. 63-110). Elsevier Applied Science London and New York.

Tambasco, D. D., Alencar, M. M., Coutinho, L. L., Tambasco, A. J., Tambasco, M. D., \& Regitano, L. C. (2000). Molecular characterization of a Nellore beef cattle sample using microsatellites and candidate genes. Rev. Bras. Zootec., 29, 1044-1049. http://dx.doi.org/10.1590/S1516-35982000000400014

Tsiaras, A. M., Bargouli, G. G., Banos. G., \& Boscos, C. M. (2005). Effect of kappa-casein and beta-lactoglobulin loci on milk production traits and reproductive performance of Holstein cows. J. Dairy. Sci., 88, 327-333. http://dx.doi.org/10.3168/jds.S0022-0302(05)72692-8 
Vasconcelos, M. F., Maldonado-Coelho, M., \& Buzzetti, D. R. C. (2003). Range extensions for the Greybacked Tachuri (Polystictus superciliaris) and the Pale-throated Serra-finch (Embernagra longicauda) with a revision of their geographic distribution. Orn. Neotrop., 14, 477-489.

Verdier-Metz, I., Coulon, J. B., \& Pradel, P. (2001). Relationship between milk fat and protein contents and cheese yield. Anim. Res., 50, 365-371. http://dx.doi.org/10.1051/animres:2001138

Wedholm, A., Larsen, L. B., Lindmark-Mansson, H., Karlsson, A. H., \& Andre'n, A. (2006). Effect of protein composition on the cheese-making properties of milk from individual dairy cows. Journal of Dairy Science, 89, 3296-3. http://dx.doi.org/10.3168/jds.S0022-0302(06)72366-9 